\title{
Comparative Affinity of Duloxetine and Venlafaxine for Serotonin and Norepinephrine Transporters in vitro and in vivo, Human Serotonin Receptor Subtypes, and Other Neuronal Receptors
}

Frank P. Bymaster, M.S., Laura J. Dreshfield-Ahmad, M.S., Penny G. Threlkeld, M.S., Janice L. Shaw, M.S., Linda Thompson, B.S., David L. Nelson, Ph.D., Susan K. Hemrick-Luecke, M.S., and David T. Wong, Ph.D.

The blockade of serotonin (5-HT) and norepinephrine (NE) transporters in vitro and in vivo by the dual 5-HT/NE reuptake inhibitors duloxetine and venlafaxine was compared. Duloxetine inhibited binding to the human NE and 5-HT transporters with $K_{i}$ values of 7.5 and $0.8 \mathrm{nM}$, respectively, and with a $K_{i}$ ratio of 9 . Venlafaxine inhibited binding to the human NE and 5-HT transporters with $K_{i}$ values of 2480 and $82 \mathrm{nM}$, respectively, and with a $K_{i}$ ratio of 30 . Duloxetine inhibited ex vivo binding to rat 5-HT transporters and NE transporters with $E D_{50}$ values of 0.03 and $0.7 \mathrm{mg} / \mathrm{kg}$, respectively, whereas venlafaxine had $E D_{50}$ values of 2 and 54 $m g / k g$, respectively. The depletion of rat brain 5-HT by p-chloramphetamine and depletion of rat hypothalamic NE by 6-hydroxydopamine was blocked by duloxetine with $E D_{50}$ values of 2.3 and $12 \mathrm{mg} / \mathrm{kg}$, respectively. Venlafaxine had $E D_{50}$ values of 5.9 and $94 \mathrm{mg} / \mathrm{kg}$ for blocking $p$-chloramphetamineand 6-hydroxydopamine-induced monoamine depletion, respectively. Thus, duloxetine more potently blocks 5-HT and $N E$ transporters in vitro and in vivo than venlafaxine.

[Neuropsychopharmacology 25:871-880, 2001]

(C) 2001 American College of Neuropsychopharmacology.

Published by Elsevier Science Inc.
KEY WORDS: Duloxetine; Venlafaxine; Depression; Norepinephrine uptake; Serotonin uptake; 5-HT receptors

Serotonin (5-HT) and norepinephrine (NE) neuronal pathways in the central nervous system are involved in

From the Neuroscience Research Division, Lilly Research Laboratories, Lilly Corporate Center, Indianapolis, IN 46285-0510

Address correspondence to: Frank P. Bymaster, Neuroscience Research Division, Lilly Research Laboratories, Lilly Corporate Center, Indianapolis, IN 46285-0510, Tel.: 317-276-9444, Fax: 317276-5546, E-mail: f.bymaster@lilly.com

Received November 27, 2000; revised April 19, 2001; accepted May 1, 2001

Online publication: 5/31/01 at www.acnp.org/citations/ Npp060101128. the mechanism of action of antidepressant drugs and, additionally, they may be involved in the pathogenesis of depression (Schildkraut 1965; Blier and de Montigny 1994; Delgado et al. 1990, 1993). However, antidepressant therapies that activate 5-HT or NE pathways have a latency of two to three weeks in response and only about $70-80 \%$ of patients are responders (Roose et al. 1986; Thase and Rush 1995). Clinical studies have indicated that combination therapy with drugs that inhibit 5-HT and NE uptake and thereby enhance activity of both neuronal systems may have improved therapeutic efficacy and possibly a faster onset of activity compared to drugs that inhibit only one monoamine uptake system (Weilburg et al. 1989; Nelson et al. 1991; Seth et al. 
1992). The tertiary amine containing tricyclic antidepressants such as imipramine and amitriptyline inhibit both NE and 5-HT uptake in vitro to variable degrees and therefore may be considered dual uptake inhibitors. However, in vivo imipramine and amitriptyline are rapidly metabolized to secondary amines that are potent and selective NE uptake inhibitors and no longer inhibit uptake of both monoamines (Wong et al. 1995). Furthermore, the tricyclic antidepressants are also antagonists at a number of neuronal receptors including muscarinic, $\alpha$-adrenergic and histamine $\mathrm{H}_{1}$ receptors, which causes significant side effects (Wong et al. 1995). Studies comparing the efficacy of tricyclic antidepressants with selective 5-HT reuptake inhibitors (SSRI) suggest that tricyclic antidepressants may be slightly more efficacious (Nelson 1998; Anderson 2000) but, arguably, compounds with adequate dual uptake inhibition have not been thoroughly evaluated clinically. In order to test the hypothesis that agents endowed with the ability to block both 5-HT and NE uptake would have supplemental efficacy in the treatment of depression, compounds such as duloxetine (Wong et al. 1993; Wong 1998) and venlafaxine (Muth et al. 1986; for review see Artigas 1995) with combined 5-HT and NE uptake inhibitor (SNRI) properties in a single molecule have been developed. Duloxetine and venlafaxine have both been shown to be clinically effective antidepressants (Berk et al. 1997; Mendels et al. 1993; Schweizer et al. 1994).

Duloxetine potently inhibits 5-HT and NE uptake processes in vitro and in vivo at similar doses (Kasamo et al. 1996; Béique et al. 1998; Wong et al. 1993; Wong 1998). However, venlafaxine has been shown to display relatively low affinity for NE uptake into rat synaptosomes compared to 5-HT uptake and for the human NE transporter versus the 5-HT transporter (Bolden-Watson and Richelson 1993; Béïque et al. 1998; Tatsumi et al. 1997). In vivo, intravenously administered venlafaxine was about 10 times more potent at prolonging recovery of firing activity of dorsal hippocampal neurons after microiontophoretically applied 5-HT than NE (Béique et al. 1998). In addition, venlafaxine after intravenous administration was about 3-fold more active at suppressing firing activity of 5-HT neurons in the dorsal raphe compared to NE neurons in locus coeruleus. Thus, it has been pointed out that there is a discrepancy between in vitro and in vivo potencies of venlafaxine for the effects on the noradrenergic neurons (Béique et al. 1999). To further address this issue, this study compared the affinity of the two compounds for human and rat 5-HT, NE, and DA transporters and blockade of 5-HT and NE uptake into rat synaptosomes. The ability of the two drugs to block 5-HT and NE transporters $e x$ vivo and block the monoamine depletion induced by 5-HT and NE transporter-specific neurotoxins was also investigated. Finally, the selectivity of duloxetine and venlafaxine was investigated by determining the inhibition of radioligand binding to a number of neuronal receptors.

\section{METHODS}

\section{Transporter Binding}

Membranes from HEK 293, MDCK and HEK293 cell lines transfected with human 5-HT, NE and DA transporters, respectively, were obtained from Receptor Biology, Inc. (Beltsville, MD). All assays were performed in triplicate in a final volume of $0.8 \mathrm{ml}$ containing each of the following: $0.2 \mathrm{ml}$ of various concentrations of drug in buffer $(50 \mathrm{mM}$ Tris $\mathrm{Cl} \mathrm{pH} 7.4,150 \mathrm{mM} \mathrm{NaCl}$, and $5 \mathrm{mM} \mathrm{KCl}$ for 5 -HT and NE transporters; $50 \mathrm{mM}$ Tris $\mathrm{Cl}, \mathrm{pH} 7.4$, and $100 \mathrm{mM} \mathrm{NaCl}$ for the DA transporter); $0.2 \mathrm{ml}$ of $\left[{ }^{3} \mathrm{H}\right]$-paroxetine $(0.2 \mathrm{nM}, 25 \mathrm{Ci} / \mathrm{mmol}$, New England Nuclear), $\left[{ }^{3} \mathrm{H}\right]$-nisoxetine $(1.0 \mathrm{nM}, 86 \mathrm{Ci} /$ mmol, New England Nuclear) or $\left[{ }^{3} \mathrm{H}\right]-W i n 35,428$ (1.0 $\mathrm{nM}, 86 \mathrm{Ci} / \mathrm{mmol}$, New England Nuclear) in buffer for the human 5-HT, NE and DA transporters, respectively; $0.2 \mathrm{ml}$ membrane $(10.3 \mu \mathrm{g}, 16.9 \mu \mathrm{g}$ or $6.2 \mu \mathrm{g}$ protein, respectively) and $0.2 \mathrm{ml}$ buffer. After incubation, $37^{\circ} \mathrm{C}$ for 40 minutes for the $5-\mathrm{HT}$ transporter and $25^{\circ} \mathrm{C}$ for 30 minutes for NE and DA transporters, the binding was terminated by rapid vacuum filtration over Whatman GF/B filters (presoaked in $0.5 \%$ polyethylenimine) and the filters were washed four times with cold $50 \mathrm{mM}$ Tris $\mathrm{Cl}$ buffer, $\mathrm{pH}$ 7.4. The filters were then placed in vials containing liquid scintillation fluid and radioactivity was measured by liquid scintillation spectrometry. Non-specific binding was determined by including separate samples of $1 \mu \mathrm{M}$ duloxetine, $10 \mu \mathrm{M}$ desipramine or $10 \mu \mathrm{M}$ nomifensine, for 5-HT, NE and DA transporters, respectively.

For binding to rat monoamine transporters, rat frontal cortical membranes were prepared by ABS, Inc. (Wilmington, DE). Briefly, male Sprague-Dawley rats were killed by decapitation, the brains rapidly removed and the frontal cortex was dissected over ice. The tissue was homogenized in 40 volumes of ice chilled $50 \mathrm{mM}$ Tris-Cl, $\mathrm{pH} 7.4$, and centrifuged at $39,800 \times \mathrm{g}$ for 10 minutes and the supernatant decanted. This process was repeated twice and the resulting homogenate was incubated at $30^{\circ} \mathrm{C}$ for 20 minutes, then centrifuged as before. The final pellets were immediately frozen at $-80^{\circ} \mathrm{C}$. After thawing, aliquots of the membranes containing $50 \mu \mathrm{g}$ protein were incubated with various concentrations of drugs, either $\left[{ }^{3} \mathrm{H}\right]$-paroxetine $(0.2 \mathrm{nM})$ or $\left[{ }^{3} \mathrm{H}\right]$-nisoxetine $(1 \mathrm{nM})$, respectively, in $50 \mathrm{mM}$ Tris $\mathrm{Cl}$, pH 7.4, $150 \mathrm{mM} \mathrm{NaCl}$ (300 mM NaCl for nisoxetine) and $5 \mathrm{mM} \mathrm{KCl}$ buffer. After a 30-min incubation at room temperature, the reaction mixtures were filtered under vacuum with a cell harvester fitted with a GF/B filter (Brandel, Gaithersburg, MD). The filters were then 
placed in vials containing liquid scintillation fluid and radioactivity was measured by liquid scintillation spectrometry. Samples containing $1 \mu \mathrm{M}$ duloxetine and 10 $\mu \mathrm{M}$ desipramine were included to assess non-specific binding to the serotonin and norepinephrine transporter, respectively.

\section{Monoamine Uptake into Synaptosomes}

Uptake of monoamines was determined according to method of Wong et al. (1993). Briefly, the uptake of $\left[{ }^{3} \mathrm{H}\right]-5-\mathrm{HT}(20 \mathrm{nM}, 21.8 \mathrm{Ci} / \mathrm{mmol}$, New England $\mathrm{Nu}-$ clear), [ $\left.{ }^{3} \mathrm{H}\right]-\mathrm{NE}(20 \mathrm{nM}, 17.2 \mathrm{Ci} / \mathrm{mmol}$, New England Nuclear), and $\left[{ }^{3} \mathrm{H}\right]-\mathrm{DA}(20 \mathrm{nM}, 45 \mathrm{Ci} / \mathrm{mmol}$, New England Nuclear) was determined in synaptosomes from cerebral cortex, hypothalamus, and striatum, respectively, of rat (Harlan Sprague-Dawley, Cumberland, IN). Accumulation of radioactivity at $4^{\circ} \mathrm{C}$ represented non-specific uptake and was subtracted from each sample. The uptake of 5-HT into platelets from humans was conducted according to the method of Wong et al. (1993).

\section{Ex vivo Uptake}

Ex vivo uptake was determined in groups of five Sprague-Dawley male rats (Harlan Sprague-Dawley) weighing 100-150 gm according to the method of Wong et al. (1993). Briefly, the rats were treated with specified doses of drugs either by the subcutaneous (s.c.) or oral route for one hour and then euthanized by decapitation. Uptake of $\left[{ }^{3} \mathrm{H}\right]-5-\mathrm{HT},\left[{ }^{3} \mathrm{H}\right]-\mathrm{NE}$ and $\left[{ }^{3} \mathrm{H}\right]-\mathrm{DA}$ in whole homogenates of cerebral cortex, hypothalamus and striatum was determined as previously described.

\section{Ex vivo Binding}

Sprague-Dawley male rats in groups of five weighing about 100-150 gm were administered s.c. either saline vehicle or varying doses of drugs and the rats were euthanized one hour after the injection. The cerebral cortices were quickly dissected and frozen on dry ice. After weighing, the tissue was homogenized in 10 volumes of $50 \mathrm{mM}$ Tris $\mathrm{Cl}$ buffer, $\mathrm{pH} 7.4$, and frozen overnight at $-80^{\circ} \mathrm{C}$. After thawing, the whole homogenates were preincubated at $37^{\circ} \mathrm{C}$ for 30 minutes. Ex vivo binding of $\left[{ }^{3} \mathrm{H}\right]$-paroxetine and $\left[{ }^{3} \mathrm{H}\right]$-nisoxetine to the 5-HT and NE transporters, respectively, was evaluated as previously described.

\section{Blockade of $p$-chloramphetamine ( $p$-CA) and 6-hydroxydopamine (6-OHDA) effects}

The 5-HT selective neurotoxin p-chloramphetamine hydrochloride (p-CA) was dissolved in distilled $\mathrm{H}_{2} \mathrm{O}$ for i.p. administration. Male Sprague-Dawley rats in groups of five weighing 180-230 grams were injected with $\mathrm{p}-\mathrm{CA}(10 \mathrm{mg} / \mathrm{kg}$ i.p.) two hours before being killed by cervical dislocation. Vehicle, duloxetine, or venlafaxine were injected one hour prior to $\mathrm{p}-\mathrm{CA}$. The tissues were quickly removed, dissected, frozen on dry ice and stored at $-70^{\circ} \mathrm{C}$ until assayed. 6-Hydroxydopamine hydrobromide (6-OHDA), a catecholaminergic neurotoxin, was dissolved in $0.1 \%$ ascorbic acid. Duloxetine or venlafaxine were injected i.p. at various doses one hour prior to intracerebroventricular injection of 6-OHDA $(50 \mu \mathrm{g} / \mathrm{rat})$ and the rats were killed one week later. Whole brain 5-HT concentrations in the p-CA study and NE concentrations in the hypothalamus for the 6-OHDA study were measured using high pressure liquid chromatography with electrochemical detection (HPLC-EC) as previously described (Fuller and Perry 1989).

\section{Determination of Binding to Neuronal Receptors and Monoamine Oxidase Activity}

Binding to dopamine $\mathrm{D}_{2}$, opiate, muscarinic, histamine $\mathrm{H}_{1}, \alpha_{1}$-adrenergic and $\alpha_{2}$-adrenergic receptors was determined using $\left[{ }^{3} \mathrm{H}\right]$-spiperone, $\left[{ }^{3} \mathrm{H}\right]$-naloxone, $\left[{ }^{3} \mathrm{H}\right]$ quinuclidinyl benzylate (QNB), $\left[{ }^{3} \mathrm{H}\right]$-pyrilamine, $\left[{ }^{3} \mathrm{H}\right]-$ WB4101 and $\left[{ }^{3} \mathrm{H}\right]$-clonidine, respectively, as previously described (Wong et al. 1993). The binding to human 5-HT receptor subtypes was determined according to published methods (5- $\mathrm{HT}_{1 \mathrm{~A}}$ and $5-\mathrm{HT}_{1 \mathrm{E}}$, Zgombick et al. 1991; 5- $\mathrm{HT}_{1 \mathrm{~B}}$ and 5- $\mathrm{HT}_{1 \mathrm{D}}$, Weinshank et al. 1992; 5- $\mathrm{HT}_{1 \mathrm{~F}}$, Adham et al. 1993; 5- $\mathrm{HT}_{2 \mathrm{~A}}, 5-\mathrm{HT}_{2 \mathrm{~B}}, 5-\mathrm{HT}_{2 \mathrm{C}}$, Wainscott et al. 1996; 5- $\mathrm{HT}_{6}$, Boess et al. 1997; 5- $\mathrm{HT}_{7}$, Bard et al. 1993). Inhibition of binding to $5-\mathrm{HT}_{4}$ and other neuronal receptors was provided by NovaScreen (Hanover, MD). Monoamine oxidase (MAO) activity in vitro was measured with rat brain mitochondria as the enzyme source with $\left[{ }^{14} \mathrm{C}\right]-5-\mathrm{HT}(100 \mu \mathrm{M}, 3.93 \mathrm{mCi} / \mathrm{mmol}$, New England Nuclear) or $\left[{ }^{14} \mathrm{C}\right]$-phenylethylamine $(12.5 \mu \mathrm{M}, 3.6$ $\mathrm{mCi} / \mathrm{mmol}$, New England Nuclear) as substrate for MAO type A or MAO type B, respectively (Fuller et al. 1970).

\section{Data Analysis}

Inhibition curves for in vitro studies were analyzed by nonlinear least-squares curve fitting to obtain $\mathrm{IC}_{50}$ values. The $\mathrm{K}_{\mathrm{i}}$ values were calculated from $\mathrm{IC}_{50}$ and $\mathrm{K}_{\mathrm{d}}$ values according to the method of Cheng and Prusoff (1973). The $K_{m}$ values for 5-HT, NE and DA uptake were 8for the 5-HT, NE and DA transporters were 0.18 , 2.5 and $22.8 \mathrm{nM}$, respectively. Statistical analyses for in vivo studies were done by analysis of variance using Tukey's Honestly Significant Difference method ( $p<$ .05) based on the mean square error.

\section{Drugs}

Duloxetine, (+)-N-methyl-3-(1-naphthalenyloxy)-3-(2-thienyl)propamine $\mathrm{HCl}$ or oxalate) and venlafaxine (1-[2- 
(dimethyl-amino)-1-(4-methoxyphenyl)-ethyl] cyclohexanol hydrochloride) were provided by the Lilly Research Laboratories, Indianapolis IN. 6-Hydroxydopamine hydrobromide and p-CA $\mathrm{HCl}$, were purchased from Sigma Chemical Co. (St Louis, MO). All other chemicals were reagent grade.

\section{RESULTS}

Duloxetine and venlafaxine dose-dependently inhibited binding of the serotonin transporter radioligand $\left[{ }^{3} \mathrm{H}\right]$-paroxetine to membranes from cells transfected with the human 5-HT transporter (Fig. 1). The $\mathrm{K}_{\mathrm{i}}$ values for duloxetine and venlafaxine were $0.8 \pm 0.04$ and $82 \pm$ $3 \mathrm{nM}$, respectively (Table 1). Duloxetine and venlafaxine inhibited binding of the NE transporter ligand $\left[{ }^{3} \mathrm{H}\right]-$ nisoxetine to membranes from cells transfected with the human NE transporter with $K_{i}$ values of $7.5 \pm 0.3$ and $2480 \pm 43 \mathrm{nM}$, respectively (Fig. 2, Table 1). The binding of $\left[{ }^{3} \mathrm{H}\right]-W i n 35,428$ to the human dopamine transporter was inhibited by duloxetine and venlafaxine with $\mathrm{K}_{\mathrm{i}}$ values of $240 \pm 23$ and $7647 \pm 793 \mathrm{nM}$ (Table 1). Duloxetine inhibited $\left[{ }^{3} \mathrm{H}\right]-5-\mathrm{HT}$ uptake into human platelets with a $\mathrm{K}_{\mathrm{i}}$ value of $0.20 \pm 0.04 \mathrm{nM}$, in close agreement to the affinity for clonal human 5-HT transporters (Wong et al. 1993).

The binding of $\left[{ }^{3} \mathrm{H}\right]$-paroxetine to rat cerebral cortical membranes was inhibited by duloxetine and venlafaxine with $\mathrm{K}_{\mathrm{i}}$ values of $0.5 \pm 0.1$ (Wong et al. 1993) and $138 \pm 21 \mathrm{nM}$, respectively, whereas the binding of $\left[{ }^{3} \mathrm{H}\right]-$ nisoxetine was inhibited with $\mathrm{K}_{\mathrm{i}}$ values of $3.6 \pm 0.3$ and $3187 \pm 186 \mathrm{nM}$, respectively (Table 1 .) The $\mathrm{K}_{\mathrm{i}}$ values for inhibition of uptake of $\left[{ }^{3} \mathrm{H}\right]-5$-HT into rat cerebral cortical synaptosomes was $4.6 \pm 1.1$ (Wong et al. 1993) and $77 \pm 2 \mathrm{nM}$ for duloxetine and venlafaxine, respectively

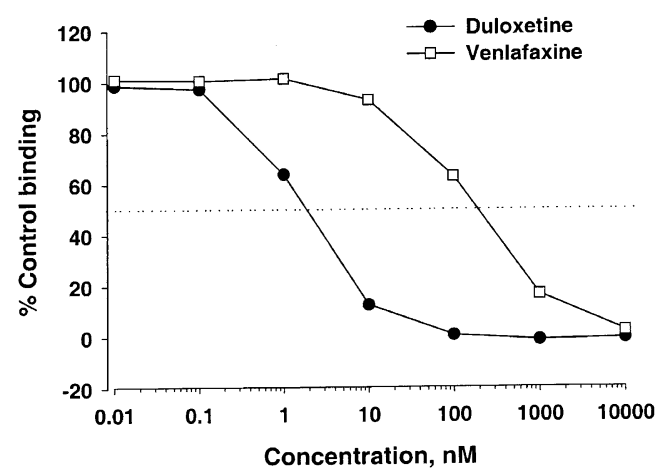

Figure 1. Concentration-dependent inhibition of $\left[{ }^{3} \mathrm{H}\right]-$ paroxetine binding to human 5-HT transporters by duloxetine and venlafaxine. Binding was determined by incubation of $\left[{ }^{3} \mathrm{H}\right]$-paroxetine $(0.2 \mathrm{nM})$ with membranes from cells transfected with human 5-HT transporters and with various concentrations of drugs for 40 minutes at $37^{\circ} \mathrm{C}$. Data are expressed as \% control specific binding.
Table 1. Inhibition of Monoamine Uptake and Transporter Binding In Vitro by Duloxetine and Venlafaxine

\begin{tabular}{|c|c|c|}
\hline \multirow[b]{2}{*}{ Measurement } & Duloxetine & Venlafaxine \\
\hline & \multicolumn{2}{|c|}{$\mathbf{K}_{\mathrm{i}}, \mathbf{n M}$} \\
\hline$\left[{ }^{3} \mathrm{H}\right]$-Paroxetine binding-human & $0.8 \pm 0.04$ & $82 \pm 3$ \\
\hline$\left[{ }^{3} \mathrm{H}\right]$-Nisoxetine binding-human & $7.5 \pm 0.3$ & $2480 \pm 43$ \\
\hline$\left[{ }^{3} \mathrm{H}\right]$-Win35428 binding-human & $240 \pm 23$ & $7647 \pm 793$ \\
\hline$\left[{ }^{3} \mathrm{H}\right]$-Paroxetine binding-rat & $0.5 \pm 0.1^{*}$ & $138 \pm 21$ \\
\hline$\left[{ }^{3} \mathrm{H}\right]$-Nisoxetine binding-rat & $3.6 \pm 0.3$ & $3187 \pm 186$ \\
\hline$\left[{ }^{3} \mathrm{H}\right]-5-\mathrm{HT}$ uptake synaptosomes & $4.6 \pm 1.1^{*}$ & $77 \pm 2$ \\
\hline$\left[{ }^{3} \mathrm{H}\right]-\mathrm{NE}$ uptake synaptosomes & $16 \pm 2.9^{*}$ & $538 \pm 43$ \\
\hline$\left[{ }^{3} \mathrm{H}\right]$-DA uptake synaptosomes & $369 \pm 38^{*}$ & $6371 \pm 1366$ \\
\hline$\left[{ }^{3} \mathrm{H}\right]-5-\mathrm{HT}$ uptake platelets-human & $0.20 \pm 0.04^{*}$ & - \\
\hline
\end{tabular}

Synaptosomal uptake of $\left[{ }^{3} \mathrm{H}\right]-5-\mathrm{HT},\left[{ }^{3} \mathrm{H}\right]-\mathrm{NE}$, and $\left[{ }^{3} \mathrm{H}\right]-\mathrm{DA}$ was in synaptosomes from rat cerebral cortex, hypothalamus, and striatum, respectively. All values determined from three or more independent experiments with at least 6 concentrations of drug in triplicate. *Data from Wong et al. (1993).

(Table 1). Duloxetine and venlafaxine inhibited uptake of $\left[{ }^{3} \mathrm{H}\right]-\mathrm{NE}$ into hypothalamic synaptosomes with $\mathrm{K}_{\mathrm{i}}$ values of $16 \pm 2.9$ (Wong et al. 1993) and $538 \pm 43 \mathrm{nM}$, respectively, and with $K_{\mathrm{i}}$ values of $369 \pm 38$ (Wong et al. 1993) and $6371 \pm 1366$ for $\left[{ }^{3} \mathrm{H}\right]$-DA uptake in rat striatal synaptosomes, respectively (Table 1 ).

Duloxetine inhibited binding to human $5-\mathrm{HT}_{6}$ and $5-\mathrm{HT}_{2 \mathrm{~A}}$ receptor subtypes with $\mathrm{K}_{\mathrm{i}}$ values of $419 \pm 89$ and $504 \pm 87 \mathrm{nM}$, respectively and had affinity of $>900$ $\mathrm{nM}$ for the other 5-HT receptor subtypes examined (Table 2). Similarly, venlafaxine had relatively low affinity for the 5-HT receptor subtypes examined (Table 2). Neither compound had significant affinity for muscarinic, dopamine $\mathrm{D}_{2}, \alpha_{1^{-}}, \alpha_{2}$-adrenergic or histamine $\mathrm{H}_{1}$ receptors and did not appreciably inhibit monoamine oxidase type A or B (Table 2). Further, duloxetine and venlafax-

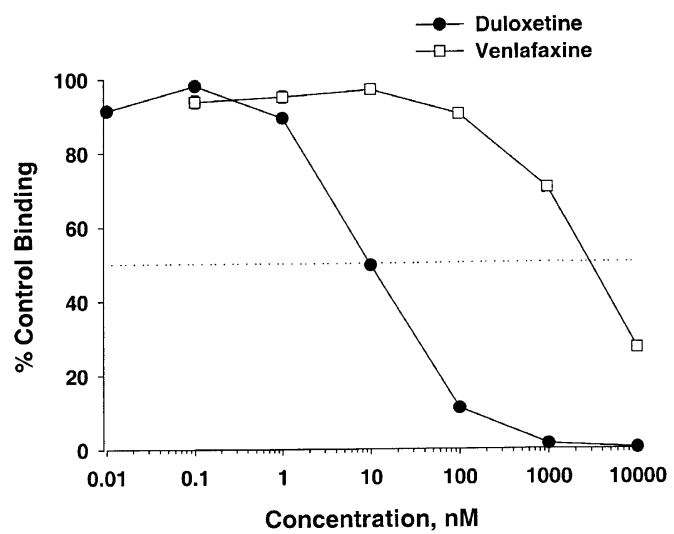

Figure 2. Concentration-dependent inhibition of $\left[{ }^{3} \mathrm{H}\right]-$ nisoxetine binding to human norepinephrine transporters by duloxetine and venlafaxine. Binding was determined by incubation of $\left[{ }^{3} \mathrm{H}\right]$-nisoxetine $(1 \mathrm{nM})$ with membranes from cells transfected with human NE transporters and with various concentrations of drugs for 30 minutes at $25^{\circ} \mathrm{C}$. Data are expressed as \% control specific binding. 
Table 2. Affinity of Duloxetine and Venlafaxine for Human 5-HT Receptor Subtypes, Other Neuronal Receptors and Blockade of Monoamine Oxidase Activity

\begin{tabular}{lcc}
\hline & Duloxetine & Venalfaxine \\
\cline { 2 - 2 } Receptor subtype & & \\
\hline $5-\mathrm{HT}_{1 \mathrm{~A}}$ & 35000 & $>10000$ \\
$5-\mathrm{HT}_{1 \mathrm{~B}}$ & $3959 \pm 810$ & $>10000$ \\
$5-\mathrm{HT}_{1 \mathrm{D}}$ & $>3000$ & $>10000$ \\
$5-\mathrm{HT}_{1 \mathrm{E}}$ & $3733 \pm 618$ & $>10000$ \\
$5-\mathrm{HT}_{1 \mathrm{~F}}$ & $4447 \pm 30$ & $>10000$ \\
$5-\mathrm{HT}_{2 \mathrm{~A}}$ & $504 \pm 87$ & $2230 \pm 723$ \\
$5-\mathrm{HT}_{2 \mathrm{~B}}$ & $2100 \pm 206$ & $>10000$ \\
$5-\mathrm{HT}_{2 \mathrm{C}}$ & $916 \pm 190$ & $2004 \pm 808$ \\
$5-\mathrm{HT}_{4}$ & $>1000^{* *}$ & $>1000^{* *}$ \\
$5-\mathrm{HT}_{6}$ & $419 \pm 89$ & $2792 \pm 431$ \\
$5-\mathrm{HT}_{7}$ & $2261 \pm 115$ & $>10000$ \\
Muscarinic-nonselective $_{\text {Dopamine }} \mathrm{D}_{2}$ & $3000^{*}$ & $>10000^{\mathrm{a}}$ \\
$\alpha_{1}$-adrenergic & 14000 & $>10000^{\mathrm{a}}$ \\
$\alpha_{2}$-adrenergic & $8300^{*}$ & $>10000^{\mathrm{a}}$ \\
$\mathrm{Histamine}_{1}$ & 8600 & $>10000^{\mathrm{a}}$ \\
Monoamine oxidase A & $2300^{*}$ & $>10000^{\mathrm{a}}$ \\
Monoamine oxidase B & $87000^{\#}$ & $>100000 \#$ \\
\hline
\end{tabular}

**All 5-HT receptor subtypes were human except for $5-\mathrm{HT}_{4}$ which was from guinea pig striatum. ${ }^{*}=$ Data in $\mathrm{IC}_{50}, \mathrm{nM}$ units from Wong et al., 1993; ${ }^{\mathrm{a}}=$ Muth et al. (1986), ${ }^{\#}=$ data in $\mathrm{IC}_{50}, \mathrm{nM}$ units.

ineneither at $1 \mu \mathrm{M}$ concentration did not significantly inhibited radioligand binding to 52 other neurotransmitter receptors, ion channel receptors, second messenger receptors, additional neurotransmitter transporters or brain/gut peptide receptors (Table 3).

The ability of duloxetine and venlafaxine to penetrate into the brain after systemic administration and interact with monoamine transporters was investigated using ex vivo binding to transporters and in vivo blockade of transporter-dependent neurotoxins. Duloxetine and venlafaxine penetrated into the brain and dosedependently inhibited ex vivo binding of $\left[{ }^{3} \mathrm{H}\right]$-paroxetine to rat cerebral cortical homogenates with $\mathrm{ED}_{50}$ values of 0.03 and $2.0 \mathrm{mg} / \mathrm{kg}$ s.c., respectively (Table 4, Fig. 3, Panel A). The ex vivo binding of $\left[{ }^{3} \mathrm{H}\right]$-nisoxetine was inhibited in a dose dependent manner with $\mathrm{ED}_{50}$ values of 0.7 and $54 \mathrm{mg} / \mathrm{kg}$ s.c., respectively, for duloxetine and venlafaxine (Fig. 3, Panel B, Table 4). Duloxetine inhibited 5-HT ex vivo uptake with $\mathrm{ED}_{50}$ values of $12.2 \pm 1.6 \mathrm{mg} / \mathrm{kg}$ p.o. and $2.0 \mathrm{mg} / \mathrm{kg}$ s.c., respectively, and $\mathrm{NE}$ ex vivo uptake with $\mathrm{ED}_{50}$ values of $14.6 \pm 2.3$ p.o. and $3 \mathrm{mg} / \mathrm{kg}$ s.c., respectively (Wong et al. 1993). Thus, duloxetine was 66 and 77 times more potent at inhibiting 5-HT and NE transporters than venlafaxine. The depletion of 5-HT in rat brain induced by $\mathrm{p}-\mathrm{CA}$ was antagonized dose-dependently by duloxetine and venlafaxine with $\mathrm{ED}_{50}$ values of 2.3 and $5.9 \mathrm{mg} / \mathrm{kg}$ i.p., respectively (Table 4, Fig. 4, Panel A). The depletion of norepinephrine levels in rat hypothalamus induced by
6-OHDA was dose-dependently blocked by duloxetine and venlafaxine with $\mathrm{ED}_{50}$ values of 12 and $94 \mathrm{mg} / \mathrm{kg}$ i.p., respectively (Table 4, Fig. 4, Panel B).

The NE/5-HT selectivity ratio of duloxetine for human transporters was 9.4 and 7.2 for rat transporters, respectively (Table 5). The NE/5-HT selectivity ratio of venlafaxine was 30 and 23 for human and rat transporters, respectively. The ratio for blockade of 5-HT and NE uptake processes in rat synaptosomes was 3.5 and 7 for duloxetine and venlafaxine, respectively. In vivo, the $\mathrm{NE} / 5-\mathrm{HT}$ selectivity ratio for ex vivo transporter binding was 23 and 27 for duloxetine and venlafaxine, respectively. The ratio for blockade of 6-OHDA/p-CA was 5.2 and 16 for duloxetine and venlafaxine, respectively.

\section{DISCUSSION}

In the present study the ability of duloxetine and venlafaxine to block 5-HT and NE transporters in vitro and in vivo was compared. Duloxetine potently inhibited binding to the human 5-HT transporters with a $\mathrm{K}_{\mathrm{i}}$ value of $0.8 \mathrm{nM}$, whereas venlafaxine was 106 times less potent. Duloxetine also potently inhibited binding to the human NE transporter with a $\mathrm{K}_{\mathrm{i}}$ value of $7.5 \mathrm{nM}$ and venlafaxine inhibited binding to the human NE transporter with a $\mathrm{K}_{\mathrm{i}}$ value of $2480 \mathrm{nM}$. Thus, venlafaxine inhibited binding to the NE transporter with 331 times lower affinity than duloxetine. Duloxetine and venlafaxine inhibited binding to the rat 5-HT and NE transporters with similar affinities to that of human transporters. The $K_{i}$ values of duloxetine for inhibition of 5-HT and NE transporters are in agreement with previously reported values in rat tissue (Béique et al. 1998; Wong et al. 1993) and for venlafaxine in human and rodent tissue (Tatsumi et al. 1997; Béique et al. 1998). The selectivity ratios of duloxetine and venlafaxine for NE/ 5-HT blockade of human transporters were 9.4 and 30, respectively. Similar selectivity ratios of 7.2 and 23 for rat NE and 5-HT transporters, respectively, were determined. Relative to their affinity for 5-HT transporters, neither drug had high affinity for the human dopamine transporter.

The dual uptake inhibitors also inhibited in vitro uptake of monoamines in synaptosomes of rat brain. Duloxetine inhibited 5-HT, NE and DA uptake with $\mathrm{K}_{\mathrm{i}}$ values of 4.6, 16 and $369 \mathrm{nM}$, respectively, in good agreement with values obtained with transporter binding in rat tissue. Venlafaxine inhibited uptake with 17, 34 and 17-fold lower potency, respectively. The NE/ 5-HT selectivity ratios of duloxetine and venlafaxine for rat synaptosomal uptake was 3.5 and 7 , respectively.

Non-selective interaction of uptake inhibitors with neuronal receptors may increase their side effect potential and new drugs in this class have been designed to have low affinity for these receptors (Wong et al. 1995). 
Table 3. Duloxetine and Venlafaxine Have Low Affinity $(>1 \mu \mathrm{M})$ for Other Neuronal Receptors*

\begin{tabular}{|c|c|}
\hline Receptor (Species) & Receptor (Species) \\
\hline \multicolumn{2}{|l|}{ Neurotransmitter receptors } \\
\hline Adenosine, A1 (R) & Glutamate, NMDA,Glycine(Stry-insen.) (R) \\
\hline Adenosine, A2 (B) & Glycine, Strychnine-sensitive (R) \\
\hline Adrenergic, $\alpha 1 \mathrm{~A}(\mathrm{R})$ & Histamine, H2 (GP) \\
\hline Adrenergic, $\alpha 1 B(R)$ & Melatonin (C) \\
\hline Adrenergic, $\alpha 2 \mathrm{~A}(\mathrm{H})$ & Muscarinic, M1 (H) \\
\hline Adrenergic, $\alpha 2 B(\mathrm{M})$ & Muscarinic, M2 (H) \\
\hline Adrenergic, $\beta 1(\mathrm{R})$ & Nicotinic (a-bungarotoxin insens) (R) \\
\hline Adrenergic, $\beta 2$ (R) & Opiate, Delta $1(\mathrm{R})$ \\
\hline Dopamine, D1 (R) & Opiate, Kappa 1 (GP) \\
\hline GABA A, Agonist Site (B) & Opiate, Mu (R) \\
\hline GABA A, Benzodiazepine, Cent. (B) & Opiate, Non-selective (R) \\
\hline Glutamate, AMPA Site (R) & Sigma 1 (GP) \\
\hline Glutamate, Kainate Site (R) & Sigma $2(\mathrm{GP})$ \\
\hline \multicolumn{2}{|l|}{ Glutamate, MK-801 Site (R) } \\
\hline \multicolumn{2}{|l|}{ Ion channels } \\
\hline Calcium Channel, Type L (R) & Glutamate, NMDA, PCP (R) \\
\hline Calcium Channel, Type N & Potassium Channel, ATP-Sens. (R) \\
\hline GABA, Chloride, TBOB Site (R) & Potassium Channel, $\mathrm{Ca}^{++}$Act., Volt Sens. (R) \\
\hline Glutamte, Chloride Site (R) & Sodium, Site $1(\mathrm{R})$ \\
\hline Glutamate, MK-801 Site (R) & Siodium, Site $2(\mathrm{R})$ \\
\hline \multicolumn{2}{|l|}{ Second messengers } \\
\hline Adenylate Cyclase, Forskolin (R) & NOS (Neuronal-Binding) (R) \\
\hline Inositol Triphosphate (R) & Protein Kinase C, PDBu (M) \\
\hline \multicolumn{2}{|l|}{ Transporters } \\
\hline Choline transporter $(\mathrm{R})$ & Adenosine transporter $(\mathrm{R})$ \\
\hline \multicolumn{2}{|l|}{ GABA transporter $(\mathrm{R})$} \\
\hline \multicolumn{2}{|l|}{ Brain/gut peptides } \\
\hline Cholecystokinin, CCK1 (CCKA) (M) & Neurokinin, NK3 (R) \\
\hline Cholecystokinin, CCK2 (CCKB) (M) & Neuropeptide, NPY1 (H) \\
\hline Neurokinin, NK1 (R) & Neurotensin (R) \\
\hline Neurokinin, NK2 (NKA) (H) & Somatostatin, Non-selective (R) \\
\hline
\end{tabular}

$*<50 \%$ inhibition of receptors by $1 \mu \mathrm{M}$ concentration of duloxetine or venlafaxine.

Abbreviations: $\mathrm{R}$, rat; $\mathrm{M}$, mouse; $\mathrm{GP}$, guinea pig; $\mathrm{B}$, bovine; $\mathrm{H}$; human.

Duloxetine and venlafaxine demonstrated remarkably low levels of interaction with a number of neuronal receptors, suggesting that they would be free from side effects due to cholinergic, histaminic, dopaminergic, and adrenergic blockade.

Duloxetine and venlafaxine also blocked uptake transporters in vivo in rats. Duloxetine blocked ex vivo 5-HT and NE transporter binding with $\mathrm{ED}_{50}$ values of 0.03 and $0.7 \mathrm{mg} / \mathrm{kg}$ s.c. Venlafaxine was 67 and 77 -fold less potent than duloxetine at inhibiting 5-HT and NE ex vivo transporter binding. Duloxetine with comparable potency blocked ex vivo uptake of 5-HT and NE into brain homogenates after s.c. and oral administration, although higher doses were required to block ex vivo uptake than ex vivo transporter binding, consistent with lower affinity at uptake blockade than inhibition of transporter binding. Duloxetine blocked transporterdependent depletion of 5-HT concentrations in rat brain by p-CA with an $\mathrm{ED}_{50}$ value of $2.3 \mathrm{mg} / \mathrm{kg}$ i.p., demonstrating in vivo blockade of the 5-HT transporter (Fuller et al. 1994). Similarly, venlafaxine blocked p-CA- induced 5-HT depletion, but was 2.6 times less potent. Blockade of NE transporter-dependent 6-OHDA-induced depletion of NE concentrations in rat hypothalamus was used to evaluate blockade of the NE transporter in vivo (Fuller et al. 1994). Duloxetine and venlafaxine blocked 6-OHDA-induced NE depletion with $\mathrm{ED}_{50}$ values of 12 and $94 \mathrm{mg} / \mathrm{kg}$ i.p., respectively. The selectivity ratio for blocking NE/5-HT transporter-dependent effects in vivo was 5.2 and 16 -fold, respectively. Thus, both drugs penetrate into the brain and inhibit both 5-HT and NE uptake processes, although considerably higher doses of venlafaxine were needed to block the NE transporter.

Thus, duloxetine compared to venlafaxine had higher affinity and more potent blockade of 5-HT and $\mathrm{NE}$ transporters in vitro and in vivo. The results are in general agreement with previously reported results on the two compounds. For example, venlafaxine was found to have 10-fold higher potency for prolonging suppression of dorsal hippocampal $\mathrm{CA}_{3}$ neuronal firing by microiontophoretically applied $5-\mathrm{HT}$ versus $\mathrm{NE}$ 
Table 4. Blockade of Ex Vivo Transporter Binding, Ex Vivo and In Vivo Monoamine Uptake by Duloxetine and Venlafaxine

\begin{tabular}{|c|c|c|}
\hline & Duloxetine & Venlafaxine \\
\hline Measurement & \multicolumn{2}{|c|}{$\mathrm{ED}_{50}, \mathrm{mg} / \mathrm{kg}$ (route) } \\
\hline $\begin{array}{l}{\left[{ }^{3} \mathrm{H}\right]-\text { Paroxetine ex vivo }} \\
\text { binding }\end{array}$ & 0.03(s.c.) & 2.0(s.c.) \\
\hline $\begin{array}{l}{\left[{ }^{3} \mathrm{H}\right]-\text { Nisoxetine ex vivo }} \\
\text { binding }\end{array}$ & 0.70 (s.c.) & 54(s.c.) \\
\hline$\left[{ }^{3} \mathrm{H}\right]-5-\mathrm{HT}$ ex vivo uptake & $\begin{array}{c}12.2 \pm 1.6(\text { p.o. })^{*} \\
2.0(\text { s.c. })^{*}\end{array}$ & ND \\
\hline$\left[{ }^{3} \mathrm{H}\right]-\mathrm{NE}$ ex vivo uptake & $\begin{array}{c}14.6 \pm 2.3 \text { (p.o.) } \\
3(\text { s.c. })^{*}\end{array}$ & ND \\
\hline $\begin{array}{l}{\left[{ }^{3} \mathrm{H}\right]-\mathrm{DA} \text { ex vivo uptake }} \\
5 \text {-HT depletion by p-CA }\end{array}$ & $>40$ (p.o.) ${ }^{*}$ & ND \\
\hline $\begin{array}{l}\text { in rat brain } \\
\text { NE depletion by } 6-\mathrm{OHDA} \\
\text { in rat hypothalamus }\end{array}$ & 2.3 (i.p.) ${ }^{* *}$ & 5.9 (i.p.) \\
\hline
\end{tabular}

*Data from Wong et al., 1993; **=data from Fuller et al., 1994, ND = not determined.

(Béique et al. 1998). Venlafaxine was also 3-fold more potent at suppressing spontaneous firing activity of 5-HT neurons in the dorsal raphe compared to suppressing NE neuronal activity in locus coeruleus (Béïque et al. 1999), although venlafaxine did not completely suppress firing in the locus coeruleus, unlike other NE uptake inhibitors including duloxetine (Kasamo et al. 1996). In the same electrophysiological paradigm, duloxetine was 4.8 -fold more potent at inhibiting spontaneously firing activity in the dorsal raphe 5-HT neurons than inhibiting NE neurons in the locus coeruleus (Kasamo et al. 1996). The data presented in this paper demonstrate at least a 16-fold difference for in vivo potency of venlafaxine to block 5-HT and NE transporterspecific neurotoxins, whereas there was only 5 -fold difference for duloxetine. The discrepancy between the affinity of venlafaxine for blocking 5-HT and NE transporters versus the potency of suppression of firing activity of cell bodies may be related to the different routes of administration, formation of active metabolites and/or sensitivity of firing of neurons. Overall, venlafaxine was consistently more potent in vivo than would be predicted from in vitro binding data, possibly due to relatively low protein binding or other bioavailability attributes (Troy et al. 1996).

Results from microdialysis studies indicate that duloxetine increases extracellular 5-HT and NE levels in frontal cortex and hypothalamus (Gobert et al. 1997; Kihara and Ikeda 1995; Engleman et al. 1995) in a similar dose range to doses that block both 5-HT and NE transporters, consistent with uptake blockade increasing extracellular levels of the neurotransmitters. Selective blockade of 5-HT and NE autoreceptors markedly augmented the duloxetine-induced increase of extracellular levels of 5-HT and NE, respectively, suggesting that in-
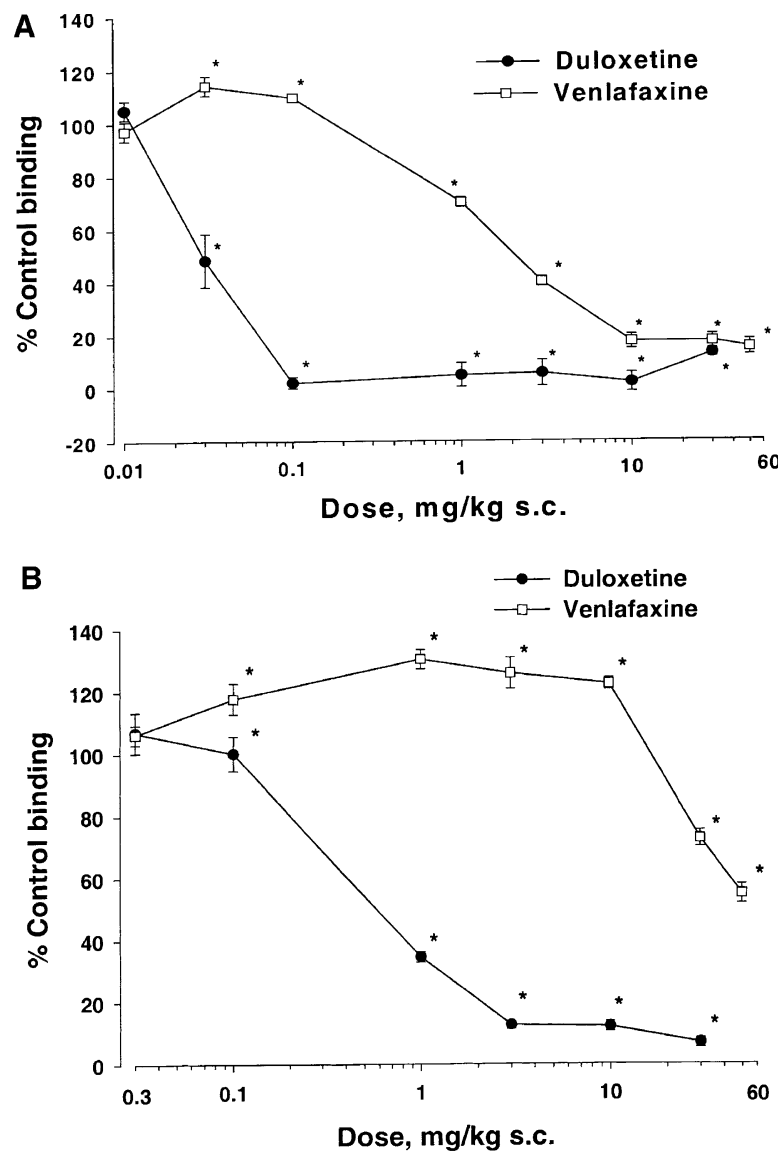

Figure 3. Dose dependent inhibition of ex vivo binding of $\left[{ }^{3} \mathrm{H}\right]$-paroxetine (Panel A) and $\left[{ }^{3} \mathrm{H}\right]$-nisoxetine (Panel B) to whole homogenates from frontal cortex of rats treated with vehicle or various doses of duloxetine or venlafaxine. Rats in groups of five were administered vehicle or drugs s.c. for one hour prior to euthanasia. Data are expressed as \% vehicle specific binding \pm standard error of the mean (SEM). $*=p<.05$.

creased levels of monoamines activated inhibitory autoreceptors (Engleman et al. 1996; Millan et al. 1998; Gobert et al. 1997). This is supported by the previously mentioned reports of inhibition of spontaneous firing activity of dorsal raphe 5-HT and locus ceruleus NE neurons by duloxetine (Kasamo et al. 1996). Duloxetine was active in several rodent behavior models of NE uptake inhibition including reserpine-induced hypothermia and tetrabenazine-induced ptosis and models for augmentation of 5-HT responses such as 5-hydroxytryptophan-induced head movements (Katoh et al. 1995). Duloxetine and venlafaxine also produced effects in the rat forced swim test consistent with blockade of multiple neurotransmitter systems (Reneric and Lucki 1998).

In summary, both duloxetine and venlafaxine inhibit 5-HT and NE uptake processes and transporter binding in vitro and in vivo. However, duloxetine has 100 -fold or higher affinity for human and rat 5-HT transporters and at least 300-fold higher affinity for NE transporters 

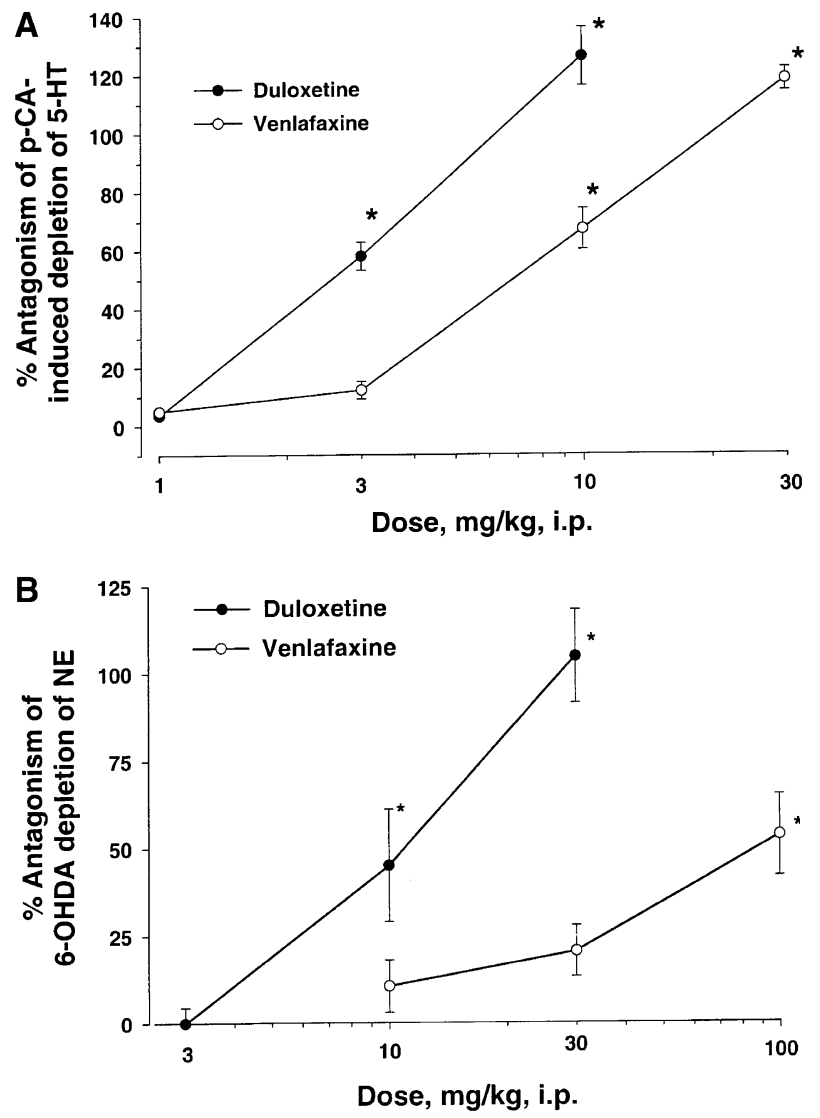

Figure 4. Blockade of p-chloramphetamine-induced depletion of brain 5-HT concentrations (Panel A) and 6-hydroxydopamine-induced depletion of hypothalamic norepinephrine (NE) concentrations (Panel B) by duloxetine and venlafaxine. $\mathrm{p}$-Chlorampetamine (p-CA, $10 \mathrm{mg} / \mathrm{kg}$ i.p.) was administered two hours before euthanasia and one hour after vehicle or various i.p. doses of duloxetine or venlafaxine. 6-hydroxydopamine (6-OHDA) was injected intracerebroventricularly $(50 \mu \mathrm{g} / \mathrm{rat})$ one hour after injection of vehicle or various i.p. doses of duloxetine or venlafaxine. The rats were euthanized one week after the 6-OHDA injection. The levels of 5-HT in whole brain and NE in hypothalamus were determined by HPLC-EC. Data are expressed as \% antagonism \pm SEM of the reduction in monoamine levels by the neurotoxin for five rats per group. The concentration of 5HT in brain of control- and p-CA-treated rats was $2.42 \pm$ 0.10 and $1.11 \pm 0.06 \mathrm{nmol} / \mathrm{gm}$, respectively. The concentration of NE in hypothalamus of control- and 6-OHDAtreated rats was $5.75 \pm 0.31$ and $2.70 \pm 0.45 \mathrm{nmol} / \mathrm{gm}$, respectively. ${ }^{*}=p<.05$.

in vitro compared to venlafaxine. In vivo, duloxetine blocks 5-HT and NE transporter dependent monoamine depletion by neurotoxins with 2.5 and 7.8-fold higher potency than venlafaxine. Overall, these data are consistent with microdialysis data indicating that duloxetine increases 5-HT and NE extracellular levels at similar doses (Engleman et al. 1995). Clinical testing of these compounds is required to determine if the supple-
Table 5. Selectivity Ratios of Duloxetine and Venlafaxine for NE and 5-HT Transporters in vitro and in vivo

\begin{tabular}{lcc}
\hline & Duloxetine & Venlafaxine \\
Measurement & Ratio NE/5-HT \\
\hline NE/5-HT human transporters & & \\
$\quad$ in vitro & 9.4 & 30 \\
NE/5-HT rat transporters in vitro & 7.2 & 23 \\
NE/5-HT uptake rat synaptosomes & & \\
$\quad$ in vitro & 3.5 & 7 \\
NE/5-HT rat transporters ex vivo & 23 & 27 \\
NE/5-HT rat ex vivo uptake (s.c.) & 1.5 & ND \\
6-OHDA/p-CA antagonism & 5.2 & 16 \\
\hline
\end{tabular}

Data from Table 1 and Table 4, ND = not determined.

mental addition of blockade of NE as well as 5-HT uptake inhibition enhances the efficacy and decreases the delay in onset of antidepressant activity compared to SSRIs.

\section{REFERENCES}

Adham N, Kao HT, Schecter LE, Bard J, Olsen M, Urquhart D, Durkin M, Hartig PR, Weinshank RL, Branchek TA (1993): Cloning of another human serotonin receptor (5-HT1F): a fifth 5-HT1 receptor subtype coupled to the inhibition of adenylate cyclase. Proc Natl Acad Sci USA 90:408-412

Anderson IM (2000): Selective serotonin reuptake inhibitors versus tricyclic antidepressants: a meta-analysis of efficacy and tolerability. J Affect Disorders 58:19-36

Artigas F (1995): Selective serotonin/noradrenaline reuptake inhibitors (SNRIs) Pharmacology and therapeutic potential in the treatment of depressive disorders. CNS Drugs 4:79-89

Bard JA, Zgombick J, Adham N, Vaysse P, Branchek TA, Weinshank RL (1993): Cloning of a novel human serotonin receptor (5-HT7) positively linked to adenylate cyclase. J Biol Chem 268:23422-23426

Béïque JC, Lavoie N, de Montigny C, Debonnel G (1998): Affinities of venlafaxine and various reuptake inhibitors for the serotonin and norepinephrine transporters. Eur J Pharmacol 349:129-132

Béïque JC, de Montigny C, Blier P, Debonnel G (1999): Venlafaxine: Discrepancy between in vivo 5-HT and NE reuptake blockade and affinity for reuptake sites. Synapse 32:198-211

Berk M, du Plessis A, Birkett M, Richardt D, on behalf of the Lilly Duloxetine study group (1997): An open-label study of duloxetine hydrochloride, a mixed serotonin and noradrenergic reuptake inhibitor, in patients with DSM-III-R major depressive disorder. Int Clin Psychopharmacol 12:137-140

Blier P, de Montigny C (1994): Current advances and trends in the treatment of depression. Trends Pharmacol Sci $15: 220-226$

Boess FG, Monsma Jr FJ, Carolo C, Meyer V, Rudler A, Zwingelstein C, Sleight AJ (1997): Functional and radioligand binding characterization of rat 5-HT6 receptors stably expressed in HEK293 cells. Neuropharmacol 36:713-720 
Bolden-Watson C, Richelson E (1993): Blockade by newly developed antidepressants of biogenic amine uptake into rat brain synaptosomes. Life Sci 52:1023-1029

Cheng YC, Prusoff WH (1973): Relationship between the inhibition constant $\left(\mathrm{K}_{\mathrm{i}}\right)$ and the concentration of inhibitor which causes a 50 percent inhibition $\left(\mathrm{IC}_{50}\right)$ of an enzymatic reaction. Biochem Pharmacol 22:3090-3108

Delgado PL, Charney DS, Price LH, Aghajanian GK, Landis H, Heninger GR (1990): Serotonin function and the mechanism of antidepressant action. Reversal of antidepressant-induced remission by rapid depletion of plasma tryptophan. Arch Gen Psychiatry 47:411-418

Delgado PL, Miller HL, Salomon RM, Licinio J, Heninger GR, Gelenberg AJ, Charney DS (1993): Monoamines and the mechanism of antidepressant action: effects of catecholamine depletion on mood of patients treated with antidepressants. Psychopharmacol Bull 29:389-396

Engleman EA, Perry KW, Mayle DA, Wong DT (1995): Simultaneous increases of extracellular monoamines in microdialysates from hypothalamus of conscious rats by duloxetine, a dual serotonin and norepinephrine uptake inhibitor. Neuropsychopharmacol 12:287-295

Engleman EA, Robertson DW, Thompson DC, Perry KW, Wong DT (1996): Antagonism of serotonin 5-HT receptors potentiates the increases in extracellular monoamines induced by duloxetine in rat hypothalamus. J Neurochem 66:599-603

Fuller RW, Hemrick-Luecke SK, Snoddy HD (1994): Effects of duloxetine, an antidepressant drug candidate, on concentrations on monoamines and their metabolites in rats and mice. J Pharmacol Exp Ther 269:132-136

Fuller RW, Perry KW (1989): Effects of buspirone and its metabolite, 1-(2-pyrimidinyl)piperazine, on brain monoamines and their metabolites in rats. J Pharmacol Exp Ther 248:50-56

Fuller RW, Warren BJ, Malloy BB (1970): Selective inhibition of monoamine oxidase in rat brain mitochondria. Biochem Pharmacol 19:2934-2936

Gobert A, Rivet J-M, Cistarelli L, Melon C, Millan MJ (1997): Alpha ${ }_{2}$-adrenergic receptor blockade markedly potentiates duloxetine- and fluoxetine-induced increases in noradrenaline, dopamine, and serotonin levels in the frontal cortex of freely moving rats. J Neurochem 69: 2616-2619

Kasamo K, Blier P, de Montigny C (1996): Blockade of serotonin and norepinephrine uptake processes by duloxetine: in vitro and in vivo studies in the rat brain. J Pharmacol Exp Ther 277:278-286

Katoh A, Eigyo M, Ishibashi C, Naitoh Y, Takeuchi M, Ibii N, Ikeda M, Matsushita A (1995): Behavioral and electroencephalographic properties of duloxetine (LY248686), a re-uptake inhibitor of noradrenaline and serotonin, in mice and rats. J Pharmacol Exp Ther 272:1067-1075

Kihara T, Ikeda M (1995): Effects of duloxetine, a new serotonin and norepinephrine uptake inhibitor, on extracellular monoamine levels in rat frontal cortex. J Pharmacol Exp Ther 272:177-183

Mendels J, Johnston R, Mattes J, Riesenberg R (1993): Efficacy and safety of b.i.d. doses of venlafaxine in a dose response study. Psychopharmacol Bull 29:169-174

Millan MJ, Brocco M, Veiga S, Cistarelli L, Melon C, Gobert
A (1998): WAY 100,635 enhances both the "antidepressant" actions of duloxetine and its influence on dialysate levels of serotonin in frontal cortex. Eur J Pharmacol 341:165-167

Muth EA, Haskins JT, Moyer JA, Husbands GE, Nielsen ST, Sigg EB (1986): Antidepressant biochemical profile of the novel bicyclic compound Wy-45,030, an ethyl cyclohexanol derivative. Biochem Pharmacol 35:4493-4497

Nelson JC (1998): Augmentation strategies with serotonergic-noradrenergic combinations. J Clin Psychiatry 59 (suppl 5):65-68

Nelson JC, Mazure CM, Bowers Jr MB, Jatlow PI (1991): A preliminary, open study of the combination of fluoxetine and desipramine for rapid treatment of depression. Arch Gen Psychiatry 48:303-307

Reneric J-P, Lucki I (1998): Antidepressant behavioral effects by dual inhibition of monoamine reuptake in the rat forced swimming test. Psychopharmacol 136:190-197

Roose SP, Glassman AH, Walsh BT, Woodring S (1986): Tricyclic nonresponders: phenomenology and treatment. Am J Psychiatry 143:345-348

Schildkraut JJ (1965): The catecholamine hypothesis of affective disorders: A review of supporting evidence. Am J Psychiatry 122:509-522

Schweizer E, Feighner J, Mandos LA, Rickels K (1994): Comparison of venlafaxine and imipramine in the acute treatment of major depression in outpatients. J Clin Psychiatry 55:104-108

Seth R, Jennings AL, Bindman J, Phillips J, Bergman K (1992): Combination treatment with noradrenaline and serotonin reuptake inhibitors in resistant depression. $\mathrm{Br}$ J Psychiatry 161:562-565

Tatsumi M, Groshan K, Blakely RD, Richelson E (1997): Pharmacological profile of antidepressants and related compounds at human monoamine transporters. Eur J Pharmacol 340:249-258

Thase ME, Rush AJ (1995): Treatment-resistant depression. In Bloom FE, Kupfler DJ (eds), Psychopharmacology: The Fourth Generation of Progress. New York, Raven Press, pp 1081-1097

Troy SM, Parker VD, Hicks DR, Boudino D, Chiang ST (1996): Pharmacokinetic interaction between multipledose venlafaxine and single dose lithium. J Clin Pharmacol 36:175-181

Wainscott DB, Lucaites VL, Kursar JD, Baez M, Nelson DL (1996): Pharmacologic characterization of the human 5-hydroxytryptamine2B receptor: evidence for species differences. J Pharmacol Exp Ther 276:720-727

Weilburg JB, Rosenbaum JF, Biederman J, Sachs GS, Pollack MH, Kelly K (1989): Fluoxetine added to non-MAOI antidepressants converts nonresponders to responders: a preliminary report. J Clin Psychiatry 50:447-449

Weinshank RL, Zgombick JM, Macchi MJ, Branchek TA, Hartig PR (1992): Human serotonin 1D receptor is encoded by a subfamily of two distinct genes: 5-HT1D alpha and 5-HT1D beta. Proc Natl Acad Sci USA 89: 3630-3634

Wong DT (1998): Duloxetine (LY248686): an inhibitor of serotonin and noradrenaline uptake and an antidepressant drug candidate. Exp Opin Invest Drugs 7:1-9 
Wong DT, Bymaster FP, Engleman EE (1995): Prozac (fluoxetine, LILLY 110140), the first selective uptake inhibitor and an antidepressant drug: twenty years since its first publication. Life Sci 57:411-441

Wong DT, Bymaster FP, Mayle DA, Reid LR, Krushinski JH, Robertson DW (1993): LY248686, a new inhibitor of serotonin and norepinephrine uptake. Neuropsychopharmacol 8:23-33

Zgombick JM, Weinshank RL, Macchi M, Schechter LE, Branchek TA, Hartig PR (1991): Expression and pharmacological characterization of a canine 5- hydroxytryptamine1D receptor subtype. Mol Pharmacol 40: 1036-1042 